\title{
Kualifikasi Pemuda Tani Perdesaan di Jawa Timur
}

\section{The Qualification Farmer Youth in Rural of East Java}

\author{
Muksin $^{1 *}$, Amri Jahi $^{2}$, Margono Slamet $^{2}$, dan Djoko Susanto ${ }^{2}$ \\ ${ }^{1}$ Dosen Politeknik Pertanian Jember \\ ${ }^{2}$ Departemen Sains Komunikasi dan Pengembangan Masyarakat, \\ Fakultas Ekologi Manusia, Institut Pertanian Bogor
}

\begin{abstract}
This research objectives are: (1) to analyze characteristics and qualification of the farmer youth, (2) to explain the implication of famer youth qualification. The research population are all youth in East Java. The technique of data collecting was cluster sampling. The number of respondents are 251 of youth. The descriptive and correspondency data analysis was used to analyse the data. The research results were: (1) The degree of farmer youth education is low category (2) The qualification of farmer youth that have activity in agricultural sector is lower than rural youth that have activity in non agricultural sector, (3) Farmer youth need facilitation to grow and develop their competencies.
\end{abstract}

Key word: qualification, farmer youth, and rural.

\section{PENDAHULUAN}

Berdasarkan beberapa kajian ditemukan bahwa para petani belum memiliki kompetensi yang dibutuhkan dalam usahatani sesuai tantangan saat ini. Pada sisi lain pemuda tani perdesaan yang diyakini sebagai generasi penerus petani belum tertangani secara serius. Beberapa indikasi dapat disebutkan antara lain, praktek-praktek usahatani yang masih relatif tradisional, ketidakterkaitan pemuda tani perdesaan dengan program penyuluhan nasional maupun lokal, dan rendahnya aspirasi pemuda tani perdesaan terhadap pekerjaan sektor pertanian sebagai mata pencaharian masa depannya. Pemuda yang dimaksud dalam penelitian ini adalah kelompok penduduk berumur 15 - 24 (The Urban Poverty Consortium of Waterloo Region, 2000; Youth for Habitat International Network, 2002; Hartell, 2005; NAPO, 2005).

Menurut Malassis (1981), tingkat pendidikan masyarakat perdesaan dan terutama masyarakat pertanian ternyata masih rendah.

\footnotetext{
* Korespondensi penulis: Telepon: 081358569951 E-mail: muksin_equator@yahoo.com
}

Di negara-negara yang sedang berkembang hampir semua hasil pertanian dan pangan dihasilkan oleh petani yang sebagian besar masih buta huruf dan tingkat pendidikannya jarang sekali lebih tinggi dari pendidikan dasar. Dengan demikian kurangnya pendidikan untuk daerah perdesaan akan menimbulkan akibat fatal. Ditambah golongan penguasa tidak merasa mempunyai kepentingan untuk meningkatkan pendidikan pekerja perdesaan, demikian juga tidak banyak daya imajinasi yang dikembangkan untuk menyesuaikan sistem pendidikan terhadap dunia perdesaan; akhirnya cara dan taraf hidup petani dewasa ini sedikit sekali memberikan dorongan kepada mereka yang mungkin berminat mendidik dirinya sendiri.

Pemuda perdesaan umumnya berada di lingkungan yang relatif identik dengan kurang tersedianya sarana dan prasarana perkembangan pemuda. Disamping itu perdesaan umumnya dihuni oleh kelompok masyarakat yang umumnya berpenghasilan relatif rendah sehingga kesulitan mengakses pendidikan formal yang kian hari kian tidak terjangkau. Konsekuensinya adalah bahwa pemuda perdesaan umumnya kurang mampu ber- 
adaptasi dengan tuntutan-tuntutan pekerjaan dan dinamika lingkungan kekinian.

Pada umumnya di wilayah seperti ini terdapat kondisi mereka yang berusia 15 tahun meliputi anak yang tidak pernah terdaftar dan banyak yang putus sekolah (Ranaweera, 1989). Menurut The Urban Poverty Consortium of Waterloo Region (2000), salah satu kelompok dalam masyarakat yang diakui dapat menjadi sebagai kelompok miskin adalah pemuda. Banyaknya pemuda miskin yang berada dalam kemiskinan seringkali tidak memperoleh bantuan atau asistensi panduan sosial. Menurut Isnawan dan Kartjono (1993) penyebab dari keadaan kemiskinan ini dapat diidentifikasi antara lain: kurangnya pengembangan sumberdaya manu-sia, kurangnya pengembangan sumberdaya alam, kurangnya lapangan/peluang/ kesempatan kerja dan berusaha, keterasingan dari sumbersumber kemajuan, dan adanya struktur masyarakat yang menghambat.

Menurut Soentoro dalam Sawit, dkk (1993) pemuda yang berusia atau yang berumur lanjut di pertanian kurang memiliki pendidikan formal yang tinggi. Secara umum seseorang yang memiliki pendidikan lebih tinggi cenderung memilih pekerjaan di sektor formal di kota. Sedangkan pekerjaan di non pertanian yang jauh lebih menonjol di perdesaan terdapat dalam sektor informal yang relatif tidak membutuhkan tingkat pendidikan formal. Dengan makin majunya pendidikan di perdesaan (paling tidak sampai saat ini) diduga akan menjadi salah satu penyebab terjadinya urbanisasi ke kota yang akhirnya akan menimbulkan masalah kesempatan kerja di kota. Menurut Ihalauw, et al (1993), berbagai studi yang dilakukan menunjukkan bahwa angkatan mudalah yang pertama-tama banyak berpaling ke bidang non pertanian. Hal ini tampaknya bukan semata-mata oleh kurangnya peluang, atau lebih rendahnya upah. Diduga hal ini dipengaruhi oleh perubahan sikap terhadap pekerjaan di bidang pertanian, terutama untuk secara langsung bergelimang lumpur.

Salah satu strategi untuk mengatasi masalah kualitas Sumberdaya manusia (SDM) petani, adalah mulai memikirkan regenerasi para pelaku pertanian. Artinya peningkatan kualitas SDM dapat mulai ditata dengan memberikan perhatian yang serius terhadap pembinaan dan pengembangan para pemuda perdesaan yang saat ini terlibat langsung atau tidak langsung dalam aktivitas pekerjaanpekerjaan di sektor pertanian. Dalam konteks ini perhatian juga seyogyanya mulai diarahkan pada para pemuda dengan lebih spesifik mencermati kualifikasi berupa ciri spesifik, yang dapat digunakan sebagai dasar menentukan strategi pengembangan pemuda tani perdesaan.

Berpijak dari kerangka pemikiran tersebut, maka penelitian ini berusaha menjawab pertanyaan penelitian berikut: (1) bagaimana distribusi karaktersitik terpilih pemuda perdesaan (2) bagaimana kualifikasi pemuda perdesaan yang saat ini bekerja di sektor pertanian, (3) bagaimana implikasi pengembangan berdasarkan kualifikasi pemuda perdesaan tersebut. Berdasar pada rumusan masalah penelitian, maka tujuan penelitian ini adalah: (1) mendeskripsikan distribusi sejumlah karakteristik pemuda perdesaan, dan (2) menganalisis kualifikasi pemuda perdesaan yang saat ini bekerja sebagai petani, dan (3) menguraikan implikasi pengembangan pemuda tani berdasarkan kualifikasi tersebut.

\section{METODE PENELITIAN}

Penelitian ini didesain sebagai penelitian survai bersifat deskriptif korelasional. Penentuan responden dilakukan dengan cluster sampling. Penentuan acak sampel dilakukan dengan tahapan: penentuan delapan kabupaten, meliputi: Kabupaten Probolinggo, Malang, Jember, Madiun, Bangkalan, Situbondo, Pacitan, dan Mojokerto. Responden terpilih berasal dari 20 RW, 20 dusun, 20 desa dari 10 kecamatan terpilih secara acak. RW digunakan sebagai unit terkecil. Hasil pengambilan sampel secara acak diperoleh 251 responden. Untuk menganalisis data digunakan analisis deskriptif dan analisis korespondensi. 
Jurnal Penyuluhan, Maret 2009 Vol. 5 No. 1

\section{HASIL DAN PEMBAHASAN}

\section{Distribusi Pemuda Berdasarkan Luas Lahan Usahatani}

Luas lahan yang dimaksud dalam penelitian ini adalah jumlah hamparan tanah (ha) yang diusahakan oleh pemuda secara mandiri atau merupakan luas lahan yang dimanfaatkan oleh orang tua dalam berusahatani dimana pemuda membantu dalam aktivitas pemanfaatan dan penge-lolaannya. Luas lahan dibagi menjadi tiga kategori, yaitu: (1) sempit, (2) sedang, dan (3) tinggi. Kategori sempit atau tidak mengusahakan adalah pemuda yang tidak berinteraksi atau membantu orang tua di lahan, kategori sedang 0,1 sampai 0,25 ha, dan luas adalah lebih dari 0,25 ha. Berdasarkan temuan di lapangan, distribusi pemuda berdasarkan luas lahan, diuraikan dalam Tabel 1. secara tradisional. Lahan yang sempit juga membatasi kelompok ini untuk melakukan eksplorasi bagaimana mengelola usahatani dalam jumlah besar atau luas. Demikian halnya dengan kelompok pemuda yang tidak memiliki lahan.

\section{Distribusi Pemuda Berdasarkan Hubungan Interpersonal}

Hubungan interpersonal dalam penelitian ini diartikan sebagai komunikasi yang dilakukan pemuda dengan orang yang ditokohkan maupun teman mengenai masalahmasalah diri, hubungan dengan orang lain, dan masalah pekerjaan termasuk masa depannya. Hubungan interpersonal dibagi menjadi tiga kategori, yaitu: (1) rendah, (2) sedang, dan (3) tinggi. Kategori rendah berarti komunikasi intensif yang dilakukan berkisar antara $0-2$

Tabel 1. Distribusi Pemuda Perdesaan berdasarkan Luas Lahan

\begin{tabular}{lll}
\hline Pemilikan Luas lahan & Jumlah (Orang) & Persentase (\%) \\
\hline Sempit & 190 & 75,7 \\
Sedang & 30 & 12,0 \\
Luas & 31 & 12,3 \\
\hline Total & 251 & 100 \\
\hline
\end{tabular}

Keterangan: Luas lahan minimum $=0$; Luas lahan maksimum $=2$ ha; rata-rata luas lahan $=0,11$ ha

Tabel 1 menunjukkan mayoritas pemuda tani adalah kategori kelompok dengan kepemilikan luas lahannya sempit atau tak berlahan. Kepemilikan lahan sempit umumnya disebabkan dan terkait dengan pola pewarisan sehingga suatu hamparan lahan terbagi-bagi menjadi luasan lebih kecil karena terdistribusi kepada ahli waris.

Pengelolaan lahan sempit yang dilaksanakan oleh pemuda tani pada hakekatnya memberikan proses pembelajaran usahatani. Pengalaman-pengalaman yang diperolah akan menjadi faktor yang mempengaruhi bagaimana kelompok pemuda ini memperlakukan usahataninya kelak. Pada faktanya dijumpai, banyak atau hampir seluruh pemuda tani melakukan kegiatan usahatani kali, kategori sedang berkisar dari 3 sampai 9 kali, dan tinggi adalah lebih dari atau sama dengan 10 kali. Distribusi pemuda perdesaan berdasarkan hubungan inter-personal, disajikan dalam Tabel 2.

Tabel 2 menunjukkan hubungan interpersonal pemuda tani sebagian besar adalah sedang, selebihnya dengan proporsi yang hampir sama adalah pemuda tani dengan kategori hubungan interpersonal rendah dan tinggi. Hasil wawancara menunjukkan teman merupakan pilihan pertama untuk berkomunikasi.

Hubungan interpersonal adalah interaksi berupa komunikasi yang dilakukan secara tatap muka oleh pemuda dengan orang lain yang dipercayai atau yang dianggap dapat bertukar pikiran. Penelitian ini mendapatkan 
Jurnal Penyuluhan, Maret 2009 Vol. 5 No. 1

bahwa preferensi pemuda dalam berinteraksi mayoritas di lakukan dengan temannya. Ratarata interaksi ini dilakukan enam sampai tujuh kali dalam sebulan. Adapun yang tertinggi adalah 30 kali dalam sebulan, dan yang paling rendah menyatakan tidak merasa berhubungan dengan orang lain dalam kadar intensif. di lingkungannya untuk kegiatan produktif. Persepsi terhadap lingkungan fisik adalah penilaian pemuda terhadap kemanfaatan kondisi geografis berupa kondisi sumberdaya alam pesisir dan lautan, pegunungan, lahan tidur, sumberdaya air dimana pemuda tani bertempat tinggal. Persepsi ini dibagi menjadi tiga kategori yaitu: (1) tidak dapat dimanfaatkan, (2) kurang dapat dimanfaatkan

Tabel 2. Distribusi Pemuda Perdesaan berdasarkan Hubungan Interpersonal

\begin{tabular}{lll}
\hline Hubungan interpersonal & Jumlah (Orang) & Persentase (\%) \\
\hline Rendah & 79 & 31,4 \\
Sedang & 92 & 36,7 \\
Tinggi & 80 & 31,9 \\
\hline Total & 251 & 100 \\
\hline
\end{tabular}

Keterangan: Hubungan interpersonal minimum $=0$; hubungan interpersonal maksimum $=30$ kali; Rata-rata hubungan interpersonal $=7$ kali.

Tingginya hubungan interpersonal pemuda dengan teman, dilakukan karena pada fase ini pemuda pada umumnya lebih memiliki kebutuhan perasaan untuk didengarkan dan pencarian jati diri. Selanjutnya terkait dengan keberadaan penyuluh, hampir seluruh pemuda menyatakan tidak pernah berhubungan dengan para penyuluh pertanian. Sebagian besar juga menyatakan tidak pernah mengetahui keberadaan penyuluh, selain itu dari kelompok pemuda ini sekitar 30\% menyatakan tidak tahu apa yang disebut penyuluh, apa fungsinya, dan apa manfaat yang diperoleh dengan keberadaan penyuluh terutama terkait dengan usahatani. Pemudapemuda yang aktivitas pekerjaannya di sektor pertanian sebagian besar juga kurang memahami adanya kelembagaan lokal seperti kelompok tani sebagai asosiasi antar petani setempat.

\section{Distribusi Pemuda Berdasarkan Persepsi}

Persepsi yang dimaksud dalam penelitian ini adalah persepsi terhadap lingkungan fisik alam khususnya terkait dengan peluang dan potensi pemanfaatan alam
(3) dapat dimanfaatkan. Hasil analisis data tentang distribusi pemuda perdesaan berdasarkan persepsi lingkungan fisik, diuraikan dalam Tabel 3.

Sebagaimana ditunjukkan pada Tabel 3, setengah dari keseluruhan pemuda tani menganggap bahwa lingkungan fisik dapat dimanfaatkan, dan hanya sebagian kecil yang menggangap lingkungan fisik tidak dapat dimanfaatkan.

Persepsi pemuda terhadap lingkungan fisik atau lingkungan alam menunjukkan positif, karena sebagaian besar pemuda menyatakan bahwa lingkungan alam yang mereka tinggali seperti lahan, sungai dan sumberdaya lain pada dasarnya dapat dimanfaatkan untuk kegiatan produktif. Jadi sebagian besar pemuda mengasumsikan bahwa seandainya memiliki keterampilan tertentu yang sesuai pastilah sumberdaya alam yang ada di sekitar mereka dapat dijadikan salah satu sumber kegiatan produktif. Pada dasarnya dengan banyaknya pemuda yang menyatakan kemungkinan pemanfaatan sumberdaya alam untuk kegiatan produktif, dapat dijadikan salah satu alasan untuk mendorong kelompok pemuda sehingga termotivasi memanfaatkan lingkungan alam yang berpotensi sebagai 
sumber penghasilan. Kemungkinan ini dapat diaktualisasikan tentu jika para pemuda difasilitasi dengan kemampuan atau keterampilan tertentu. Namun demikian sebagian kelompok pemuda yang lebih kecil jumlahnya menyatakan bahwa lingkungan alam dimana
Hasil pengolahan data menggunakan analisis corespondency terhadap pemuda perdesaan yang beraktivitas dalam bidang pertanian menunjukkan ukuran kemiripan tidak nyata untuk membedakan berdasarkan kemiripan kategori yang ditunjukkan nilai

Tabel 3. Distribusi pemuda pedesaan berdasarkan persepsi lingkungan alam

\begin{tabular}{lll}
\hline Persepsi lingkungan fisik & Jumlah (Orang) & Persentase (\%) \\
\hline Tidak dapat dimanfaatkan & 10 & 4,0 \\
Kurang dapat dimanfaatkan & 112 & 44,6 \\
Dapat dimanfatkan & 129 & 51,4 \\
\hline
\end{tabular}

mereka tinggali kurang dapat dimanfaatkan. Persepsi terhadap lingkungan alam ini terutama berkaitan dengan pemahaman bahwa mengolah lahan atau sumberdaya lain dinilai belum menjadi kegiatan produktif dan tidak akan banyak menghasilkan uang. Persepsi semacam ini juga banyak dipengaruhi oleh sosialisasi teman-teman sebaya, yang sudah pernah atau sedang menjalani usaha atau bekerja di kota. Disamping itu orang tua juga memberikan sosialisasi yang kurang tepat, terkait dengan pesimisme orang tua atas pekerjaan-pekerjaan yang berkaitan dengan eksplorasi dan budidaya yang memanfaatkan sumberdaya alam. Terdapat dorongan dari orang tua agar para anak-anaknya mencari pekerjaan yang "lebih baik" dan "lebih menjanjikan" di perkotaan.

\section{Kualifikasi Pemuda Tani Perdesaan dan Implikasinya}

Pengertian kualifikasi dalam penelitian ini adalah keseluruhan karakteristik umum yang dapat memberikan gambaran terhadap ciri-ciri pemuda perdesaan yang beraktivitas dalam sektor pertanian dan yang memiliki aspirasi pertanian. Ciri-ciri ini didasarkan pada kemiripan kategori pada masing-masing variabel yang dilihat. Analisis ini diharapkan dapat memberikan gambaran bagaimana kualitas SDM pemuda perdesaan khususnya yang memiliki aktivitas pekerjaan utama dan aspirasi dalam bidang usahatani. rata-rata alpha cronbach 0,451. Artinya meskipun terjadi pengelompokkan atau pembedaan dengan ciri-ciri pada pemuda yang bekerja di bidang pertanian dan non pertanian, perbedaan keduanya tidak nyata.

Berdasarkan analisis corespondency tersebut dapat dijelaskan bahwa pemuda yang memiliki aktivitas kerja di sektor pertanian (PBP) umumnya memiliki ciri-ciri pendidikan formalnya rendah dan juga sedang, pendidikan nonformalnya rendah, konsumsi media rendah, persepsi terhadap kelompok dan persepsi terhadap orang tua umumnya rendah, dan umumnya berumur kategori lanjut. Kondisi ini tidak terlalu berbeda dengan pemuda yang bekerja di sektor non pertanian (PBNP). Perbedaaan keduanya terletak pada pendidikan nonformal dan persepsi terhadap orang tua. Pada kedua variabel, pemuda yang bekerja di sektor non pertanian umumnya pendidikan nonformalnya terkategori sedang, dan persepsi terhadap orang tua relatif lebih positif.

Kualifikasi dalam penelitian ini diperlukan sehingga dapat memberikan gambaran bagaimana kualitas pemuda perdesaan bila dilihat dari kelompok PBP dan PBNP. Berdasarkan analisis correspondency tersebut dapat dijelaskan bahwa kelompok PBP dan beraspirasi pertanian kualifikasinya relatif lebih rendah dibandingkan dengan kelompok PBNP yang beraspirasi pekerjaan pada sektor non pertanian.

Pendidikan formal, pendidikan nonformal, dan pendidikan informal yang dalam hal ini dilihat pada tingkat konsumsi media, 
persepsi lingkungan sosial dan fisik, adalah faktor-faktor yang menentukan secara alamiah dan instrumental terhadap peningkatan kapasitas seseorang. Pendidikan formal dan nonformal merupakan variabel instrumental yang mengantarkan pemuda memiliki kemampuan kognitif, afektif, dan psikomotor yang dilakukan secara sengaja dan implementasinya mengikuti standar kebijakan nasional yang dikeluarkan pemerintah Indonesia. Nampak bahwa mayoritas PBP memiliki tingkat pendidikan formal dan non formal yang relatif rendah. Kondisi ini akan memberikan tingkat kesulitan sekaligus tantangan yang berat bagi pemuda tani untuk dapat merealisasikan citacitanya. Pada sisi lain tuntutan lingkungan eksternal mengharuskan dan mensyaratkan individu pada saat ini, untuk terus-menerus melakukan perubahan sehingga dapat beradaptasi melalui proses peningkatan kapasitasnya.

Adapun persepsi lingkungan sosial dan konsumsi media yang rendah akan memberikan hambatan bagi PBP untuk mencapai dan meningkatkan kapasitasnya. Persepsi pada dasarnya adalah cara menilai atau memandang seseorang terhadap sesuatu Hal ini terkait dengan kesulitan melakukan dialog yang sebenarnya dibutuhkan dalam proses perkembangan pemuda dalam menapaki masa dewasa atau masa depannya. Pada sisi lain dalam banyak penelitian disebutkan, bahwa sumberdaya petani saat ini (sebagai orang tua pemuda) dapat dikategorikan rendah.

Hasil penelitian ini juga mengungkapkan bahwa PBP umumnya terkategori sebagai kelompok pemuda lanjut. Ini memberikan indikasi bahwa pilihan bekerja di sektor pertanian adalah pilihan yang relatif sudah mantap kalau dinilai dari umur pemuda. Sebaliknya kebanyakan pemuda kelompok awal dan madya mayoritas bukanlah pemuda yang memilih aspirasi bekerja di bidang pertanian. Pada dasarnya umur seseorang akan berkorelasi dengan pengalaman hidup yang diperoleh. Dengan karakter pendidikan formal dan non formal yang relatif rendah, maka pengalaman usahatani yang dijalankan oleh kelompok lanjut utamanya diperoleh dari hasil melihat dari orang tua sebagai model dalam melaksanaan aktivtas pekerjaan, teman, ataupun lingkungan sekitar. Konsekuensinya praktik-praktik pertanian tradisional (yang saat ini dilakukan oleh orang tua) akan tetap dilaksanakan sebagai rujukan dan pilihan.

Berdasarkan kualifikasi pada pemuda tani perdesaan yang telah diuraikan menunjukkan bahwa sebenarnya kelompok ini dapat dikategorikan sebagai kelompok miskin atau marginal. Beberapa penciri seperti: pendidikan formal dan nonformal rendah, adanya atau kepemilikan lahan yang sempit, dan keterdedahan terhadap media relatif tinggi utamanya materi-materi yang bersifat hiburan, dan minimnya kontak dengan sumber informasi seperti penyuluh memberikan suatu kondisi yang kurang menguntungkan bagi kelompok ini. Pada dasarnya minimnya daya ekonomi dengan indikator rendahnya penghasilan dan minimnya kontak dengan sumber informasi yang pada dasarnya sangat dibutuhkan akan melemahkan daya pemuda untuk mengakses pengetahuan dan keterampilan, informasi yang relevan, dan terdedahnya dengan sangat kuat dengan budaya konsumerisme akan semakin meneguhkan ketidakberdayaan kelompok pemuda tani. Selanjutnya keseluruhan faktor-faktor ini akan berdampak pada rendahnya produktivitas, kelemahan daya saing, dan ketidakmampuan dalam mengelola sumberdaya yang dimiliki dan sumberdaya alam yang ada di sekitarnya, sehingga pada akhirnya pemuda tani memiliki ketidakmampuan secara individu untuk dapat beradaptasi dengan lingkungan saat ini yang demikian dinamis bahkan sangat cepat berubah. Kondisi-kondisi ini mengisyaratkan dibutuhkannya fasilitasi yang tepat dengan berlandaskan pada kondisi spesifik pemuda perdesaan, keperluan pengembangan kompetensi yang tepat dan berorientasi pada perkembangan tantangan kini dan masa yang akan datang.

Pemuda tani perdesaan (PTP) sebenarnya adalah kelompok produktif yang secara konsepsional berada pada masa perkembangan. Pada masa perkembangan kebutuhan terhadap sarana perkembangan dan kesempatan untuk melakukan aktivitas yang bermanfaat menjadi urgen untuk mengop- 
timalkan pencapaian yang optimal secara fisik dan non fisik.

Perkembangan optimal dengan demikian memerlukan fasilitasi dari luar diri pemuda. Namun demikian fasilitasi akan berhasil dan relatif lebih mudah dilakukan jika PTP memiliki motivasi yang kuat sebagai implikasi dari kesadaran akan kebutuhan dirinya. Upaya membantu memfasilitasi peningkatan kemampuan dan kualitas PTP harus didasarkan pada kondisi faktual pemuda dan karakteristik lingkungan PTP.

Ketidakberdayaan kelompok PTP pada dasarnya dapat dilihat dari beberapa sudut pandang. Pada sisi kelompok pemuda sendiri, kondisi dengan kemampuan beradaptasi dengan lingkungan yang rendah akan meningkatkan rasa tidak percaya diri, terasingkan dari keberadaan lingkungannya (teralienasi), dan frustasi. Pada sisi lingkungan, kelompok pemuda yang tidak produktif, frustasi, akan menjadikan beban bagi masyarakat dimana pemuda tinggal. Indikasi munculnya penyimpangan perilaku dapat dilihat misalnya semakin meningkatnya kasus-kasus pemaksaan anak (pemuda) terhadap orang tua untuk merealisasikan keinginan tertentu, kurang tahan untuk bersabar dalam merealisasikan keinginan, aktivitas mencari penghasilan dengan menempuh jalan yang bertentangan dengan norma adat atau hukum seperti terlibat jaringan penjualan "togel" dan bentuk-bentuk perjudian lainnya.

Pemikiran untuk memfasilitasi peningkatan kapasitas pemuda sehingga memiliki kemampuan yang layak, harus didasarkan pada kondisi faktual kualifikasi pemuda. Perlu dilakukan implementasi kebijakan terutama dalam merespon fenomena-fenomena kualifikasi dari berbagai karak-teristik yang relatif rendah.

Guna merespon kondisi-kondisi tersebut, maka kebijakan yang diperlukan adalah memfasilitasi PTP umumnya sehingga mampu untuk belajar pada pendidikan formal, minimal pada tahapan sekolah dasar dan sekolah menengah pertama atau pendidikan forml yang disetarakan. Selanjutnya diperlukan fasilitasi terhadap pelaksanaan pendidikan nonformal yang dapat difokuskan spesifik pada PTP.
Khusus untuk kebijakan pendidikan nonformal dapat dilakukan melalui implementasi proses penyuluhan baik yang dikhususkan pada kelompok PTP maupun terintegrasi dengan penyuluhan-penyuluhan kepada orang dewasa. Pendekatan implementasinya didasarkan pada pertimbangan: pemanfaatan kelembagaan kepemudaan yang sudah ada, proses penyuluhan yang sudah dilaksanakan, dan berdasarkan aktivitas pekerjaan yang sudah dilakukan oleh PTP.

Berdasar pada kebutuhan prakarsa kebijakan yang diperlukan, maka pendekatan yang terintegrasi antar pihak (pelaku) yang bermaksud untuk memberdayakan pemuda harus dilakukan. Adanya keterbatasanketerbatasan yang dimiliki oleh pemerintah, berimplikasi pada kebutuhan peran masyarakat yang lebih signifikan. Asumsinya pemuda adalah bagian dari masyarakat, yang juga banyak dipengaruhi oleh orang tua dan lingkungan sekitarnya dalam hal ini masyarakat. Khusus pada lingkup penelitian ini, pendidikan pada dasarnya memfasilitasi pengembangan kapasitas dalam hal ini PTP sebagai komunitas yang tidak berdaya. Pengembangan kapasitas pada dasarnya merupakan upaya agar proses pengembangan yang dilakukan pada masyarakat sehingga mampu melakukan proses pengembangan oleh masyarakat sendiri atau masyarakat lokal.

Kapasistas lokal dalam konteks ini diartikan kemampuan (ability) orang lokal untuk mengartikulasikan kebutuhannya dan mengidentifikasi tindakan-tindakan dalam rangka menyelesaikan kebutuhan tersebut. Kapasitas lokal juga bermakna kemampuan (fisik dan mental) untuk memobilisasi dan mengorganisasikan sumberdaya lokal dan ekstra lokal dalam rangka menemukan dan mewujudkan tujuan yang telah didefinisikan secara jelas. Dalam konteks ini, keberhasilan dapat diwujudkan jika terdapat kemampuan manajemen kapasitas oleh pemerintahan lokal, termasuk di dalamnya kepemimpinan dan kekuatan untuk mendukung kelembagaan.

Berlandaskan pada kualifikasi PTP, perlu diupayakan suatu implementasi program kegiatan yang mampu meningkatkan kemudahan, sarana dan prasana pemuda perdesaan 
untuk belajar. Kesatuan kegiatan harus meliputi pendekatan kepada orang tua, meningkatkan akses belajar dan sarana belajar sehingga mudah menemukan informasi, secara regular dilaksanakan kegiatan pendidikan nonformal dalam hal ini penyuluhan yang relevan sesuai dengan analisis kebutuhan. Selain itu kegiatan yang mampu mengakomodir pemuda dalam mengaktualisasikan diri, harus diorientasikan pada fasilitasi kesertaan dalam pengambilan keputusan dan menyatakan pendapat, berinteraksi dengan teknologi informasi dan komunikasi, kepemimpinan, dan proses komunikasi yang mendorong kemudahan untuk memunculkan gagasan.

Upaya untuk membantu memberdayakan atau memfasilitasi pengembangan pemuda perdesaan yang terkategori marginal, harus didasarkan pada peningkatan kemapuan diri pemuda sendiri untuk mampu memecahkan masalah-masalah yang dihadapi secara mandiri dengan mempertimbangkan dan mengoptimalkan sumberdaya yang dimilikinya. Dengan demikian fasilitasi terhadap penyelenggaraan belajar pemuda perdesaan, harus didasarkan pada pandangan bahwa pemuda adalah warga yang sudah akan menginjak masa dewasa.

Mempertimbangkan pandangan terhadap warga belajar, kemudian tujuan pendidikan, isi atau materi pembelajaran, dan proses pembelajaran, maka harus diupayakan fasilitator mendasarkan pada situasi yaitu ciriciri pemuda sebagai individu menjelang masa dewasa, kebutuhan meningkatkan kepercayaan diri, nilai-nilai yang masih berlaku sebagai warga desa, minimnya sarana belajar, dan tantangan kekinian serta masa depan.

Umumnya pemuda perdesaan terutama yang sudah tidak mengikuti kegiatan pendidikan formal sudah berpikir mencari penghasilan atau bahkan sudah bekerja bagi keberlangsungan hidupnya, serta berpikir untuk persiapan berkeluarga. Dengan demikian pada dasarnya kelompok ini sudah dapat dikategorikan sebagai kelompok dewasa dini dengan ciri-ciri yang lebih mendekati orang dewasa yang umumnya memiliki kebutuhan dan keinginan tertentu untuk diwujudkan. Di sisi lain dalam struktur keluarga kelompok pemuda berada di bawah tanggungjawab orang tua yang seringkali di posisikan bukan sebagai anak kecil dan juga bukan sebagai orang dewasa.

Implikasinya proses pendidikan harus didasarkan pada paradigma pendidikan orang dewasa (POD), tetapi tetap dengan mempertimbangkan kebutuhan pemuda untuk dapat bersosialisasi dengan teman sebaya, mengembangkan kepercayaan diri, kebutuhan dihargai, dan kebutuhan pemuda lainnya yang bersifat immateri.

\section{KESIMPULAN}

Pemuda tani perdesaan mayoritas bekerja pada luas lahan yang sempit atau tidak memiliki lahan, sangat minim berkomunikasi dengan penyuluh, dan memiliki persepsi yang positif bahwa pada dasarnya lingkungan alam di sekitarnya dapat dimanfaatkan.

Kualifikasi pemuda perdesaan yang saat ini bekerja di sektor pertanian lebih rendah dibandingkan pemuda perdesaan yang bekerja di sektor non pertanian.

Pemuda tani perdesaan dapat dikategorikan sebagai kelompok marginal dan memerlukan fasilitasi khusus untuk membantu meningkatkan kemampuannya.

\section{DAFTAR PUSTAKA}

Hartell C. G. 2005. "HIV/Aids In South Africa: A Review Of Sexual Behavior Among Adolescents". Adolescence. 40: 171 [Jurnal on-line]; Diperoleh dari http://www.proquest.org/pqdweb;

Internet; Diakses pada 26 April 2005.

Ihalauw J., Kartoredjo J. S., Suwondo, K. dan Widjajanto, L. 1993. Penguasaan Tanah Serta Implikasinya terhadap Ketetatan Budidaya dalam Mubyarto. 1993. Peluang Kerja dan Berusaha di Pedasaan. Yogyakarta: BPFE.

Ismawan, B dan Kartjono. 1993. Kemandirian Kelompok Swadaya dan Peranannya dalam Penciptaan Peluang Kerja dan Berusaha di Perdesaan dalam Mubyarto. 
Jurnal Penyuluhan, Maret 2009 Vol. 5 No. 1

1993. Peluang Kerja dan Berusaha di Pedasaan. Yogyakarta: BPFE

Malassis L. 1981. Dunia Perdesaan Pendidikan dan Perkembangan. Jakarta: Gunung Agung.

[NAPO]. "Introduction to Youth Poverty" [Article on-line]; Diperoleh dari http://www.napo-onap.ca; Internet; Diakses pada 18 Januari 2005.

Ranaweera A. M. 1989. Pendekatan NonKonvensional dalam Pendidikan Tingkat Dasar. Semarang: IKIP Semarang Press.

Sawit H., Yusuf Saefuddin, dan Sri Hartoyo. 1993. Aktivitas Non Pertanian Pola Musiman dan Peluang Kerja Rumah
Tangga di Pedasaan Jawa Di dalam: Mubyarto. 1993. Peluang Kerja dan Berusaha di Pedasaan. Yogyakarta: BPFE

The Urban Poverty Consortium of Waterloo Region. 2000. "Youth Poverty" [Article on-line]; Diperoleh dari http://www. waterlooregion.org; Internet; Diakses pada 23 Januari 2005.

Youth Association for Habitat International Network. "Youth Associaton for Habitat and Agenda 21" [Article on-line]; Diperoleh dari http://www.youthforhab. org.tr/eng/document/youthrights.

Internet; Diakses pada 19 Januari 2005. 